\title{
The biodiversity cost of reducing management intensity in species-rich grasslands: Mowing annually vs. every third year
}

Per Milberg, Malin Tälle, Håkan Fogelfors and Lars Westerberg

The self-archived postprint version of this journal article is available at Linköping University Institutional Repository (DiVA):

http:// urn.kb.se/ resolve?urn=urn:nbn:se:liu:diva-141735

N.B.: When citing this work, cite the original publication.

Milberg, P., Tälle, M., Fogelfors, H., Westerberg, L., (2017), The biodiversity cost of reducing

management intensity in species-rich grasslands: Mowing annually vs. every third year, Basic and Applied Ecology, 22, 61-74. https:// doi.org/ 10.1016/j.baae.2017.07.004

Original publication available at:

https:/ / doi.org/ 10.1016/j.baae.2017.07.004

Copyright: Elsevier

http:// www.elsevier.com/

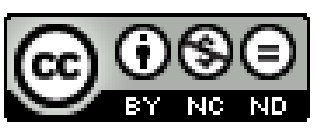




\section{The biodiversity cost of reducing management intensity in}

species-rich grasslands: Mowing annually vs. every third

year

Per Milberga,* (permi@ifm.liu.se),

Malin Tälle (malin.talle@liu.se),

Håkan Fogelfors ${ }^{\mathrm{b}}$ (hakan.fogelfors@slu.se,

Lars Westerberg ${ }^{\mathrm{a}}$ (lars.westerberg@liu.se)

${ }^{\text {a }}$ IFM Biology, Conservation Ecology Group, Linköping University, SE-

58183 Linköping, Sweden

${ }^{\mathrm{b}}$ Department of Crop Production Ecology, Swedish University of

Agricultural Sciences, Box 7043, SE-750 07 Uppsala, Sweden

*Corresponding author.

E-mail adress: permi@ifm.liu.se 


\section{Abstract}

Mowing is an important management method for species-rich seminatural grasslands in Europe. Since mowing is costly, it is important to find a balance between mowing frequency and conservation benefits. We compared vegetation data from eleven field trials situated in southern Sweden that involved two mowing regimes, annually and every third year, as well as a no-management control. After approximately 14 years, mowing every third year showed (i) a drop in species richness and Shannon and Gini-Simpson diversity indices, (ii) an increase in woody species, and (iii) increases in tall-grown species. However, there were no apparent changes in (iv) species that were indicative of poor management, nor (v) those indicating good management. For one of the trials, data after 38 years were also evaluated. Compared with annual mowing, there were strong negative changes in the number of species in the untreated control, while the results were conflicting for mowing every third year. In conclusion, the expected loss of conservation values from reduced mowing intensity was 50 to $60 \%$ of the loss after abandonment. The outcomes, however, varied among the eleven sites.

\section{Keywords:}

Cutting, Indicators, Meta-analysis, Mowing, Odds ratio, Response ratio, Semi-natural grassland, Sweden 


\section{Introduction}

Ongoing changes in agriculture mean that it is a challenge for conservation efforts to maintain the rich biodiversity that is associated with traditionally managed semi-natural grasslands in Europe (Kull \& Zobel 1991, Poschlod et al. 2009, D’Aniello et al. 2011, Wilson et al. 2012, Habel et al. 2013, Babai \& Molnár 2014). Grazing and mowing are the two options for exploiting the biomass of grass-dominated vegetation, and both seem relatively similar in regard to the benefit that they provide for preserving biodiversity (Tälle et al. 2015, 2016). However, the amount of available cattle for conservation-oriented grazing is decreasing (Kumm 2003), while the labour costs for annual mowing in most cases remain high (Schreiber et al. 2009, Török et al. 2011).

Although not the first choice, reduction of management intensity might allow more land to be managed. Managers can skip mowing every second year and thereby double the acreage that is mowed or reduce the stocking density (e.g. a limited number of animals spread over a larger area; or rotational grazing with grazing-free periods). Theoretically, there should be an optimal balance between the available resources (e.g., number of animals, cost of labour), area covered and biodiversity benefits provided. Put another way, a larger area with relaxed management (intensity or type) might be preferred over a smaller area under the best management 
option as long as the losses in biodiversity are acceptable. Hence, it is important to estimate the "cost", in terms of lost biodiversity, for reducing management intensity (Marriott et al. 2004).

As grazing intensity is difficult to estimate and to maintain at a uniform level over many years, experiments that vary the stocking density are less suited to address this issue than experiments assessing the effect of different mowing intensities on biodiversity. The results from studies comparing the effect of higher and lower mowing intensities vary, with some in favour of higher mowing intensities (e.g., Köhler et al. 2005, Noordjik et al. 2009, and others in favour of lower mowing intensities (e.g., Everwand et al. 2014, Körösi et al. 2014). However, few studies have examined the effect of mowing less than once per year (but see e.g., Bakker et al. 2002). Hence, there is still room for improvement in our understanding of the effect of different mowing intensities on biodiversity. In general, the outcome could be expected to resemble secondary succession when management ceases, that is, woody species and tall-grown species increase while the diversity indices and richness decrease.

Here, we analyse data from a series of eleven field trials in southern Sweden in which mowing every year was compared with mowing every third year as well an unmanaged control. Two of these 
trials have previously been reported in full elsewhere (Hansson \& Fogelfors 2000, Wahlman \& Milberg 2002) but then with mainly qualitative assessment of treatment and ignoring the substantial value of including replications over sites (which was the original intention of the series of trials). We intended to estimate the rate of loss of conservation values based on all eleven grasslands over 14 years. At one site, data were also available after 38 years. More specifically, when converting to more infrequent mowing, we expected:

(i) a decrease in the number of species and diversity indices (Shannon, Gini-Simpson, Shannon evenness)

(ii) a decrease of species indicative of good management (i.e. one that maintains species-richness typical of traditional grassland management)

(iii) an increase in species indicative of poor management

(iv) an increase in woody species

(v) an increase in tall-grown species

\section{Materials and methods}

\section{Study sites}

In the early 1970s, a long-term experiment was established at eleven experimental sites at nine locations in southern Sweden (Fig. 1). Two of the locations (Ekenäs, Tagel) had two experimental sites each. The mean 
annual temperature in southern Sweden is approximately $6{ }^{\circ} \mathrm{C}$, mean annual precipitation is 500-1000 mm (Alexandersson et al. 1991) and growing period is 180-220 days (Sjörs 1999).

The sites were selected with the aid of local conservation authorities, to ensure continued management for a long time, preferably 20 years (Steen 1976). The aim was also to strive for diversity in soil type, and land use history, thereby reflecting the type of marginal grassland that in the early 1970s was at risk of abandonment and becoming overgrown (Steen 1976). Overall, the study sites represent different types of open land that have been under grazing for a long time (Steen 1976). Before the start of the experiments, most of the sites were grazed. However, one of the sites (Dämkärr) had not been managed for three years, and one site (Gränö) had been mowed for a decade and then irregularly fertilized. Furthermore, two of the sites (Gränö and Tagel/former field) had a history as fertilized arable field (up until ca. 10 and 20 years prior to onset of the experiments, respectively) (Table 1, Hansson 1991). It is worth noting that these former, small arable fields were embedded in oldstyle, small-scale agricultural landscapes, where there used to be some degree of alteration between mowing and arable farming (Ekstam \& Forshed 1996). It is also worth noting that during its 20 years under grazing, Tagel/former field had been regularly fertilized (Hansson 1991). 
To conclude, at the onset, three of the trials (Dämkärr, Gränö, Tagel/former field) might have been less floristically diverse and consequently less suited to manifest losses in biodiversity relevant for conservation. However, their response to treatments turned out well within the range of the other eight experiments (Fig. 2, 3E and 3F), and they were therefore included in our analyses.

The sites differed in vegetation type and productivity, but the majority of the sites were of the mesic meadow type (Table 1; Hansson 1991). If using the Council Directive 92/43/EEC on the conservation of natural habitats and of wild fauna and flora (Swedish Environmental Protection Agency 2011), the sites are semi-natural dry grasslands (6210), hay meadows in submontane zones (6510), Fennoscandian wooded pastures (9070) or wet meadows (Molinion caeruleae) (6410).

\section{Experimental design}

The experiment was set up with the aim of assessing vegetation changes as a result of the introduction of several management methods (Steen 1976; Fogelfors 1982; Hansson 1991). For the present study, we used three management methods: annual mowing, mowing every third year, and an untreated control. Treatment plots $(5 \mathrm{~m} \times 20 \mathrm{~m})$ were established in a randomized block design with two replicates. Mowing took place in late July or early August using a scythe or sickle bar mower. Because all 
of the experiments were surrounded by grazed grasslands, the plots were fenced.

\section{Vegetation sampling}

Fieldwork was conducted in July, before mowing took place. Initial vegetation assessments were conducted, but the protocol for data collection varied between sites (Steen 1976). Most experiments were assessed again after approximately 8 years (Fogelfors 1982), this time using a standardized protocol. All of the sites were again visited in 19867 using the standardized protocol, which involved using five fixed $1 \mathrm{~m}^{2}$ subplots per treatment plot (at Bräcke, three $1 \mathrm{~m}^{2}$ fixed subplots were used).

We used the presence/absence of species in the subplots to generate a frequency per treatment plot. In some of the analyses, we used data as given in previous reports (Steen 1976, Fogelfors 1982, Hansson 1991), but corrected for numerous typing errors (see Tälle et al. 2015 for details on data retrieval and transcription). In some analyses, we first created a dataset with a species list that allowed analyses of species-wise data over the eleven trials. The latter meant deleting some records of only partially identified records (e.g., deleting Luzula sp., since the majority of Luzula records were identified at the species level). It also meant creating groups of species that had been identified with different levels of 
precision (e.g., “other Agrostis spp.” i.e., all Agrostis recorded excluding A. gigantea). Finally, we merged the woody taxa, which were always infrequent, into "all woody species". The nomenclature follows that of Karlsson (1998).

One trial (Sättra ängar) has been managed continuously since 1973, so here we used data collected in 1973 (Steen 1976), 1980 (Fogelfors 1982), 1986 (Hansson 1991) and 2011 (unpublished). Data also exist for 2000, but because a different methodology was used when assessing the vegetation and because the survey was conducted late in the season, well after mowing (Wahlman \& Milberg 2002), we decided not to consider them in the present analysis.

\section{Classification of plant species}

To enable a comparison of data collected from different sites that differ in species composition, we simplified the data in some analyses by classifying grassland species as indicators. Based on previous experience (Milberg et al. 2014, Tälle et al. 2014, 2015), we chose a welldocumented indicator system that targeted species-rich semi-natural grasslands in southern Sweden (Ekstam \& Forshed 1992). The purpose of this system is to frame grassland plants into gradients of abandonment. In the book,which is widely used by practitioners, species are classified according to the rate at which a species is lost during secondary 
succession from grassland to forest, i.e. when management ceases (four classes: decrease or loss within 3-5 years of abandonment, decrease or loss within 10-15 years, decrease or loss within 25-35 years, increase in abundance). In addition, species are given indicator values - moisture, light, acidity, nitrogen - similar to Ellenberg's, and we here used the soil nitrogen availability (three classes: preference for sites poor, intermediate or rich in soil N). We classified species as (i) indicators of good management for species richness if they decrease in early succession stages (classes A and B) and grow in sites poor in nitrogen (N1); (ii) indicator species of poor management if they do not decrease until later successional stages (classes C and D) and grow in nutrient-poor sites or sites with moderate levels of nitrogen (classes N1 and N2).

\section{Statistical analyses}

Species richness and diversity

The treatment effect on the number of species recorded in the 5 (or 3) $\mathrm{m}^{2}$ sampled per treatment were calculated as ln-transformed response ratios (RR). To avoid bias in the RR due to small sample sizes, Lajeunesse's (2011) method of calculating $\ln (\mathrm{RR})$ was used:

$\ln (\mathrm{RR})=\ln \left(\left(\mathrm{X}_{\mathrm{T}} / \mathrm{X}_{\mathrm{C}}\right)+1 / 2\left[\mathrm{SD}_{\mathrm{T}}{ }^{2} / \mathrm{N}_{\mathrm{T}} \mathrm{X}_{\mathrm{T}}{ }^{2}-\mathrm{SD}_{\mathrm{C}}{ }^{2} / \mathrm{N}_{\mathrm{C}} \mathrm{X}_{\mathrm{C}}{ }^{2}\right]\right)$

where $\mathrm{X}$ is the mean, $\mathrm{T}$ is mowing every third year, $\mathrm{C}$ is annual mowing, SD is the standard deviation and $\mathrm{N}$ is the sample size. Corresponding 
$\ln (\mathrm{RR})$ values were calculated for two diversity indices (Shannon, GiniSimpson) and for evenness (Shannon). Using a meta-analysis tool (Comprehensive Meta-analysis version 2; Biostat, Inc. 2006; www.metaanalysis.com), we then calculated the weighted average, based on the random effects model, for the eleven trials. A positive value of $\ln (\mathrm{RR})$ signifies a more positive effect of mowing every third year.

To estimate the rate of change, we used trial-wise estimates of species numbers and diversity, where comparable, to follow the development of $\ln (\mathrm{RR})$ over time. Three trials had data from three sampling occasions, five from two (the remaining three had only been surveyed once with the standardized protocol). The slopes of the trialwise regressions for these eight trials were then used to calculate the average and weighted average (giving the three sites with the best data more weight).

\section{Species indicating good or poor management}

We analysed the data using an odds ratio as a way of overcoming differences in the vegetation composition and the differing number of subplots. This analysis method compared the odds of a species recorded being an indicator, contrasting two different treatments. For each type of indicator, we first calculated the total number of indicators and nonindicators (i.e., all other species) per subplot or per treatment plot if 
subplots were not used. We then summed the number of indicators and non-indicators per treatment plot (if subplots were surveyed). This measure reflects the frequency of the indicator species and non-indicator species in each treatment plot.

To compare annual mowing with mowing every third year, or the untreated control, a random effects meta-analysis was performed using Comprehensive Meta-analysis.

The effect sizes were measured as log odds ratio (logOR):

$$
\log \mathrm{OR}=\log [(\mathrm{A} \times \mathrm{D} /(\mathrm{B} \times \mathrm{C})]
$$

where $\mathrm{A}=$ the frequency of indicators in the annual mowing treatment; $\mathrm{B}$ $=$ the frequency of non-indicators in the annual mowing treatment; $\mathrm{C}=$ the frequency of indicators in the alternative treatment; and $\mathrm{D}=$ the frequency of non-indicators in the alternative treatment. A positive logOR signifies higher odds of finding indicators in plots with annual mowing. Since each trial contained two blocks, each trial contributed two entries to the meta-analysis.

Woody species and tall-grown species

Since the majority of woody species were observed only once or twice, we based these calculations on the occurrence of woody species in subplots, irrespective of species identity. Because these data contained 
several zeros, $\ln (\mathrm{RR})$ was deemed to be less suited for the analysis, and we instead calculated the difference in occurrence after 11-14 years over the eleven trials between mowing every third year and annual mowing. For comparison, differences between the untreated control and annual mowing were also calculated.

In a similar manner, we calculated species-wise differences between mowing every third year, or the untreated control, and annual mowing. Only species occurring in at least seven of the 22 experimental blocks were considered (fewer occurrences were not considered to appropriately reflect between-site variation), which meant 56 species in total. For these species, we extracted information on plant height (Canopy Height) from the LEDA traitbase (Kleyer et al. 2008; http://www.unioldenburg.de/en/biology/landeco/research/projects/leda/, accessed August 2016), using averages when there was more than one entry for a species. Plant height was then used in a regression analysis to predict the treatment differences.

\section{Results}

\section{Effect on species richness and diversity}

As expected, there was an overall drop in $\ln (\mathrm{RR})$ for the number of species when mowing every third year was compared with annual mowing, but with considerable variation between sites (Fig. 2A). The 
sites showing the weakest effect sizes were the moist one (Gränö, Ekenäs Moist, Andersby), while the drier sites Österplana (dry) and Ekenäs Mesic (dry/mesic) showed the strongest effect sizes (Fig. 2A). The two diversity indices also decreased, albeit the Gini-Simpson decreased only very modestly (Fig. 2B andC), while there were no apparent changes in evenness (Fig. 2D). Generally, after 11-14 years, the losses were approximately twice the magnitude when comparing the untreated control with mowing every third year (estimates of Overall in Fig. 2).

At least for Fig 2A, there was an apparent coincidence of the driest sites (Österplana, Ekenäs Mesic) being the ones with the strongest effect sizes while the three moist sites (Gränö, Ekenäs Moist, Andersby) displayed weak effect sizes. Furthermore, there was a tendency for the more species-rich sites to show the stronger effect sizes (linear regression: $\mathrm{P}=$ $0.1288)$.

\section{The rate of change}

The estimates of change in $\ln (\mathrm{RR})$ for species number and Shannon diversity suggested that the loss was slower, approximately half the rate, when mowing every third year than for the untreated control (Fig. 3A and B). For the Gini-Simpson and evenness indexes, there were much smaller, but still clear losses, and if anything, the untreated control performed better than mowing every third year (Fig. 3C and D). 
Trial-wise trajectories in $\ln (\mathrm{RR})$ for the species number varied greatly among sites: in some trials, there were increases when mowing every third year compared with annual mowing (Fig. 4A), and in some trials, there were increases in $\ln (\mathrm{RR})$ in the untreated control (Fig. 4B).

At the site at Sättra, which had been followed for 38 years, the two blocks showed differing trends over time: one lost species when mowed every third year compared with annully while the other block gained species (Fig. 5). The plots of the untreated control also seemed to react differently (Fig. 5; no assessment was performed after 38 years because the dense tree canopy that had developed in the plots had recently been thinned to eliminate the shading of adjacent plots).

\section{Change in species indicating good or poor management}

The odds of finding indicators of good management showed no apparent change over time, nor did the odds of finding indicators of poor management (Fig. 6).

\section{Effects on woody and tall-grown species}

Species-wise analyses showed that a majority of species occurred less frequently when mowing was performed every third year, and for many of these species, the negative trend was stronger in the untreated control treatment (Fig. 7). While there were 15 species that showed a significant decrease with relaxed management, there was only one species group 
with a significant increase, woody species (Fig. 7), hence confirming our hypothesis.

Comparing the height of species with the values shown in Fig. 7, there was a strong positive relationship $\left(\mathrm{F}_{(1,54)}=16.759 ; \mathrm{R}^{2}=0.2368\right.$; $\mathrm{P}=0.000143$ ), i.e., short-grown species mainly became less frequent with relaxed mowing (Fig. 8).

\section{Discussion}

By using data from eleven replicated field trials, we showed that relaxed management, in this case mowing every third year, means losing biodiversity attributes in vegetation after 11-14 years compared to annual mowing. This was most clearly seen in data on the species number (Fig. 2A) as well as for some of the species (Fig. 7) but also in one diversity index (Fig. 2B). However, it is important to note that the effect sizes were quite small (an $\ln (\mathrm{RR})$ of -0.1 represents e.g. comparing species richness of ten and eleven species), despite the management trials running between 10 and 15 years. That the evenness index (Fig. 2D) seemed unaffected suggests that the balance among the species resilient to relaxed management did not change much. It is also clear that effect sizes were largest in dry sites and smallest in moist sites, and a tendency for the species-rich sites to exhibit larger effect sizes. 
More surprising was the lack of treatment effects on the odds of finding indicator species (Fig. 6). This particular system of indicator species has previously been shown to be relatively sensitive to management effects in grasslands in the area in which these trials were conducted (Milberg et al. 2014, Tälle et al. 2015). Using indicator species has sometimes been subjected to criticism (Siddig et al. 2016), and their usefulness is known to vary in reliability along environmental gradients (e.g., Jansson et al. 2009, Zettler et al. 2013). Hence, some caution is always needed when interpreting results based on indicator species.

As hypothesized, short-grown species were most likely to decrease when the mowing frequency was relaxed, confirming previous findings (Hejcman et al. 2007) and suggesting one or several possible mechanisms: impaired seed regeneration due to a denser canopy or litter accumulation (e.g., Laborde \& Thompson 2013, Loydi et al. 2013, Kladivová \& Münzbergová 2016), impaired growth due to litter accumulation (Kelemen et al. 2013), or species being outcompeted by more tall-grown species through shading or root interactions (Lamb et al. 2009, Kiær et al. 2013). From the point of view of management, our finding might suggest the allocation of parts of a grassland - preferably with low grass sward - to an annual mowing regime, while performing 
more extensive management of more tall-grown areas (e.g., every second year).

As hypothesized, the occurrence of woody species increased with relaxed management. Even if these woody perennials are cut every third year, they seem to have secured enough resources to re-sprout - or have more chances for successful seed establishment - despite the more dense and tall-grown vegetation with relaxed management. Whether these small woody plants are benign or will create an increasing obstacle for mowing remains to be seen. Shoots might be larger when grown from older stumps than from younger stumps or from seed, hence requiring more force to be cut by a scythe or being more likely to remain after the passage of a sickle-bar mower.

By comparing the eleven trials, it is apparent that changes can occur at different rates (Fig. 4) and even differ in direction (Fig. 4B and Fig. 5). Hence, basing conclusions on a single field trial involves a degree of risk of reaching false conclusions (cf Ioannidis 2005). The false discovery rate in science seems to be generally underrated (Button et al. 2013, Nosek et al. 2015), particularly so within ecology, where studies often have low power and there is a reluctance to repeat studies (Parker et al. 2016). Within conservation biology, the total research budget is limited, leading to a data deficiency (Milberg 2014). It was particularly noteworthy that 
the outcome after 38 years - when a potential treatment effect should have had plenty of time to manifest itself - differed between the two blocks (Fig. 5). Therefore, apart from the experimental error that manifested in between-site differences, there was also substantial variation within a site, despite sharing identical land use history and similar edaphic factors.

The majority of studies on effects of different mowing intensities focus on comparing annual mowing with mowing at a higher intensity (e.g. mowing two times a year). Studies comparing annual mowing with mowing at a lower intensity are fewer, and results are often varying. While some studies reveal similar results as in the present study, with a more positive effect of the higher mowing frequency (e.g. Köhler et al. 2005), others reveal results in favour of mowing every second year (Gosteli 1996, Bakker et al. 2002, Ameloot et al. 2006). A study by Ryser et al. (1995) revealed similar effects of annual mowing and mowing every second year but a negative effect of mowing every fifth year. Consequently, this might suggest that from a conservation perspective mowing every second year is sufficient, while mowing more seldom can have a more negative effect. However, we expect that the most suitable mowing intensity also depends on specific site conditions, e.g. more productive grasslands require a higher management intensity to facilitate 
biomass and nutrient removal (Al-Mufti et al. 1977; Oelmann et al. 2009).

\section{Rate of change}

There is no apparent unit by which to assess biodiversity changes (Milberg 2014), but indices might be more universal than the number of species and so on. In the present study, we chose a palette of different outcomes, several expressed as a response ratio (Fig. 3 and Fig. 4) or odds ratio (Fig. 6). For others, the nature of the data forced us to use the difference between the treatment (mowing every third year) and control (annual mowing) (Fig. 5, Fig. 7). The odds and response ratios are transferable and comparable with other such estimates (e.g., Tälle et al. 2016), while raw treatment differences are context-specific. Furthermore, to aid interpretation, we added corresponding data contrasting the untreated control with annual mowing because this approach hopefully allows more comparisons with other studies.

The loss of biodiversity when turning to mowing every third year was approximately half of that seen in abandonment for the two clearly affected response ratios (number of species, Shannon). The median for the species-wise reductions was $62 \%$ of that seen after abandonment, but with large differences among species, confirming previous reports from two of the experimental sites (Hansson \& Fogelfors 2000, Wahlman \& 
Milberg 2002), where the outcome of mowing every third year was intermediate between annual mowing and abandonment.

\section{Implications}

Mowing every third year resulted in biodiversity losses, and a more realistic frequency might therefore be mowing every second year (Bakker et al. 2002; Köhler et al. 2005) or skipping one year in three. Such relaxed management might not be perfect for grassland plants, but could be beneficial for many insects, most notably pollinators and butterflies (e.g., Littlewood et al., 2012; van Klink et al., 2015, Milberg et al. 2016).

There are subsidies available for farmers in the EU, e.g., to support the management of semi-natural grasslands. Because these subsidies represent a substantial societal investment, it is important that funds be used in the best possible way. They should function as an incentive for farmers to maintain management that might otherwise not be justified economically. If adjusting subsidies to the actual cost of maintaining mowing, one method is to halve the subsidy if converting to mowing every second year, but such a move is likely to decrease farmers' incentive for maintaining management. Also, the quality of the fodder harvested would be substantially reduced as mowing every second year would mean mixing fresh plant growth with previous year's litter. 


\section{Acknowledgements}

We thank those who helped initiate, maintain and monitor the long-term field trials analysed here. The Swedish Environmental Protection Agency initially funded these trials. Financial support for our study was provided by the Swedish Board of Agriculture.

\section{References}

Alexandersson, H., Karlström, C., Larsson-McLann, S., 1991.

Temperaturen och nederbörden i Sverige 1961-1990. Referensnormaler. Sveriges Meteorologiska och Hydrologiska Institut, SMHI Meteorologi No. 81.87 pp. In Swedish.

Al-Mufti, M.M., Sydes, C.L., Furness, S.B., Grime, J.P., Band, S.R., 1977. A quantitative analysis of shoot phenology and dominance in herbaceous vegetation. Journal of Ecology 65, 759-791.

Ameloot, E., Verheyen, K., Bakker, J.P., De Vries, Y., Hermy, M.. 2006. Lon-term dynamics of the hemiparasite Rhinanthus angustifolius and its relationship with vegetation structure. Journal of Vegetation Science 17, $637-646$. 
Babai, D., Molnár, Z., (2014) Small-scale traditional management of highly species-rich grasslands in the Carpathians. Agriculture, Ecosystems \& Environment 182, 123-130.

Bakker, J.P., Elzinga, J.A., de Vries, Y., 2002. Effects of long-term cutting in a grassland system: perspectives for restoration of plant communities on nutrient-poor soils. Applied Vegetation Science 5, 107120.

Button, K.S., Ioannidis, J.P.A., Mokrysz, C., Nosek, B.A., Flint, J., Robinson, E.S.J., Munafò, M.R., 2013. Power failure: why small sample size undermines the reliability of neuroscience. Nature Reviews Neuroscience 14, 365-376.

D’Aniello, B., Stanislao, I., Bonelli, S., Balletto, E., 2011. Haying and grazing effects on the butterfly communities of two Mediterranean-area grasslands. Biodiversity \& Conservation 20, 1731-1744.

Ekstam, U., Forshed, N., 1992. Om hävden upphör; kärlväxter som indikatorarter i ängs- och hagmarker. Naturvårdsverket Förlag, in Swedish.

Ekstam, U., Forshed, N. 1996. Äldre fodermarker: Betydelsen av hävdregimen i det förgångna, målstyrning, mätning och uppföljning. Naturvårdsverket Förlag, in Swedish. 
Everwand, G., Rösch, V., Tscharntke, T., Scherber, C., 2014.

Disentangling direct and indirect effects of experimental grassland management and plant functional-group manipulation on plant and leafhopper diversity. BMC Ecology 14:1.

Fogelfors, H. 1982. Det marginella odlingslandskapets öppethållande.

Del II. Resultat och utvärdering av långvariga försök med olika skötselmetoder. - Swedish University of Agricultural Sciences. Department of Ecology and Environmental Research. Report No. 11. In Swedish.

Gosteli, M. 1996. Diversities of snail faunas and ecological relationships between snail communities and vegetation in dry habitats of the northern Swiss Jura (Gastropoda: Prosobranchia et Pulmonata). Malakologische Abhandlungen 181, 107-123.

Habel, J.C., Dengler, J., Janišová, M., Török, P., Wellstein, C., Wiezik, M., 2013. European grassland ecosystems: threatened hotspots of biodiversity. Biodiversity \& Conservation 22, 2131-2138.

Hansson, M. 1991. Management of semi-natural grassland. Results of a fifteen-year- old field experiment in south and central Sweden. - Swedish University of Agricultural Sciences, Uppsala. Department of Ecology and 
Environmental Research. Report No. 45. In Swedish with English summary.

Hansson, M., Fogelfors, H., 2000. Management of semi-natural grassland; results from a 15-year old experiment in southern Sweden. Journal of Vegetation Science 11, 31-38.

Hejcman, M., Klaudisová, M., Schellberg, J., Honsová, D., 2007. The Rengen Grassland Experiment: plant species composition after 64 years of fertilizer application. Agriculture, Ecosystems \& Environment 122, 259-266.

Ioannidis, J.P. 2005. Why most published research findings are false. PLoS Medicine 2(8), p.e124

Jansson, N., Bergman, K.-O., Jonsell, M., Milberg, P., 2009. An indicator system for identification of sites of high conservation value for saproxylic oak (Quercus spp.) beetles in southern Sweden. Journal of Insect Conservation 13, 399-412.

Karlsson, T., 1998. Förteckning över svenska kärlväxter. [The vascular plants of Sweden - a checklist]. Svensk Botanisk Tidskrift 91, 241-560. In Swedish. 
Kelemen, A., Török, P., Valkó, O., Miglécz, T., Tóthmérész, B., 2013. Mechanisms shaping plant biomass and species richness: plant strategies and litter effect in alkali and loess grasslands. Journal of Vegetation Science 24, 1195-1203.

Kiær, L.P., Weisbach, A.N., Weiner, J., 2013. Root and shoot competition: a meta-analysis. Journal of Ecology 101, 1298-1312.

Kladivová, A., Münzbergová, Z., 2016. Interacting effects of grazing and habitat conditions on seedling recruitment and establishment. Journal of Vegetation Science 27, 834-843.

Kleyer, M., Bekker, R.M., Knevel, I.C., Bakker, J.P., Thompson, K., Sonnenschein, M., Poschlod, P., Van Groenendael, J.M., Klimeš, L., Klimešová, J., Klotz, S., Rusch, G.M., Hermy, M., Adriaens, D., Boedeltje, G., Bossuyt, B., Dannemann, A., Endels, P., Götzenberger, L., Hodgson, J.G., Jackel, A.-K., Kühn, I., Kunzmann, D., Ozinga, W.A., Römermann, C., Stadler, M., Schlegelmilch, J., Steendam, H.J., Tackenberg, O., Wilmann, B., Cornelissen, J.H.C., Eriksson, O., Garnier, E., Peco, B. (2008) The LEDA Traitbase: a database of life-history traits of the Northwest European flora. Journal of Ecology 96, 1266-1274.

Köhler, B., Gigon, A., Edwards, P.J., Krüsi, B., Lagenauer, R. Lüscher, A., Ryser, P., 2005. Changes in the species composition and conservation 
value of limestone grasslands in Northern Switzerland after 22 years of contrasting managements. Perspectives in Plant Ecology, Evolution and Systematics 7, 51-67.

Körösi, Á., Szentirmai, I., Batáry, P., Kövér, S., Örvössy, N. 2014. Effects of timing and frequency of mowing on the threatened scarce large blue butterfly: A fine-scale experiment. Agriculture, Ecosystems and Environment 196, 24-33.

Kull, K., Zobel, M., 1991. High species richness in an Estonian wooded meadow. Journal of Vegetation Science 2, 711-714.

Kumm, K.-I., 2003. Sustainable management of Swedish seminatural pastures with high species diversity. Journal for Nature Conservation 11, 117-125.

Laborde, J., Thompson, K., 2013. Colonization of limestone grasslands by woody plants: the role of seed limitation and herbivory by vertebrates. Journal of Vegetation Science 24, 307-319.

Lajeunesse, M.J., 2011. On the meta-analysis of response ratios for studies with correlated multi-group designs. Ecology 92, 2049-2055. 
Lamb, E.G., Kembel, S.W., Cahill, J.F., 2009. Shoot, but not root, competition reduces community diversity in experimental mesocosms. Journal of Ecology 97, 155-163.

Littlewood, N.A., Stewart, A.J.A., Woodcock, B.A., 2012. Science into practice: how can fundamental science contribute to better management of grasslands for invertebrates? Insect Conservation \& Diversity 5, 1-8. Loydi, A., Eckstein, R.L., Otte, A., Donath, T.W., 2013. Effects of litter on seedling establishment in natural and semi-natural grasslands: a metaanalysis. Journal of Ecology 101, 454-464.

Marriott, C., Fothergill, M., Jeangros, B., Scotton, M., Louault, F., 2004. Long-term impacts of extensification of grassland management on biodiversity and productivity in upland areas. A review. Agronomie 24, 447-462.

Milberg, P., 2014. Evidence-based vegetation management: prospects and challenges. Applied Vegetation Science 17, 604-608.

Milberg, P., Akoto, B., Bergman, K.-O., Fogelfors, H., Paltto, H., Tälle, M., 2014. Is spring burning a viable management tool for semi-natural grasslands? Applied Vegetation Science 17, 429-441. 
Milberg, P., Bergman, K.-O., Cronvall, E., Eriksson, Å.I., Glimskär, A., Islamovic, A., Jonason, D., Löfqvist, Z., Westerberg, L., 2016. Flower abundance and vegetation height as predictors for nectar-feeding insect occurrence in Swedish semi-natural grasslands. Agriculture, Ecosystems \& Environment 230, 47-54.

Noordjik, J., Delille, K., Schaffers, A.P., Sýkora, K.V., 2009. Optimizing grassland management for flower-visiting insects in roadside verges. Biological Conservation 142, 2097-2103.

Nosek, B.A., Aarts, A.A., Anderson, C.J., Anderson, J.E. et al., 2015. Estimating the reproducibility of psychological science. Science 349 (6251). aac4716-aac4716.

Oelmann, Y., Broll, G., Hölzel, N., KLeinebecker, T., Vogel, A., Schwartze, P., 2009. Nutrient impoverishment and limitation of productivity after 20 years of conservation management in wet grasslands of north-western Germany. Biological Conservation 142, 2941-2948.

Parker, T.H., Forstmeier, W., Koricheva, J., Fidler, F., Hadfield, J.D., Chee, Y.E., Kelly, C.D., Gurevitch, J., Nakagawa, S., 2016. Transparency in ecology and evolution: real problems, real solutions. Trends in Ecology \& Evolution 31, 711-719. 
Poschlod, P., Baumann, A., Karlik, P., 2009. Origin and development of grasslands in central Europe. - In: Veen, P., Jeffersson, R., de Smidt, J., van der Straaten, J. (eds.), Grasslands in Europe - of high nature value. KNNV Publishing, pp. 12-25.

Ryser, P., Langenauer, R., Gigon, A., 1995. Species richness and vegetation structure in a limestone grassland after 15 years management with six biomass removal regimes. Folia Geobotanica \& Phytotaxonomica 30, 157-167.

Schreiber, K.-F., Brauckmann, H.-J., Broll, G., Krebs. S. and Poschlod, P. 2009. Artenreiches Grünland in der Kulturlandschaft. 35 Jahre Offenhaltungsversuche Baden-Württemberg. - Verlag Regionalkultur, in German.

Siddig, A.A., Ellison, A.M., Ochs, A., Villar-Leeman, C., Lau, M.K. 2016. How do ecologists select and use indicator species to monitor ecological change? Insights from 14 years of publication in Ecological Indicators. Ecological Indicators 60, 223-230.

Sjörs. H. 1999. The background: geology, climate and zonation. Acta Phytogeogr. Suecica 84: 5-14.

Steen, E. 1976. Det marginella odlingslandskapets öppethållande.

Dokumentation i långvariga försök med olika skötselmetoder. 
Lantbrukshögskolan, Avdelningen för ekologisk miljövård, Uppsala. In Swedish.

Swedish Environmental Protection Agency. 2011. Natura 2000. < http://www.naturvardsverket.se/Miljoarbete-i-samhallet/Miljoarbete-i-

Sverige/Uppdelat-efter-omrade/Naturvard/Skydd-av-natur/Natura2000/>, accessed 31 August 2015. In Swedish.

Tälle, M., Bergman, K.-O., Paltto, H., Pihlgren, A., Svensson, R., Westerberg, L., Wissman, J., Milberg, P., 2014. Mowing for biodiversity: grass trimmer and knife mower perform equally well. Biodiversity \& Conservation 23, 3073-3089.

Tälle, M., Fogelfors, H., Westerberg, L., Milberg, P., 2015. The conservation benefit of mowing vs. grazing for management of speciesrich grasslands: a multi-site, multi-year field experiment. Nordic Journal of Botany 33, 761-768.

Tälle, M., Deák, B., Poschlod, P., Valkó, O., Westerberg, L., Milberg, P., 2016. Grazing vs. mowing: a meta-analysis of biodiversity benefits for semi-natural grassland management. Agriculture, Ecosystems \& Environment 222, 200-212.

Török, P., Vida, E., Deák, M., Lengyel, S., Tóthmérész, B., 2011. Grassland restoration on former croplands in Europe: an assessment of 
applicability of techniques and costs. Biodiversity \& Conservation 20, 2311-2332.

van Klink, R., van der Plas, F., van Noordwijk, C.G.E., Wallis de Vries, M.F., Olff, H., 2015. Effects of large herbivores on grassland arthropod diversity. Biological Reviews 90, 347-366.

Wahlman, H., Milberg, P., 2002. Management of semi-natural grassland vegetation; evaluation of long-term experiment in southern Sweden. Annales Botanici Fennici 39, 159-166.

Wilson, J.B., Peet, R.K., Dengler, J., Pärtel, M., 2012. Plant species richness: the world records. Journal of Vegetation Science 23, 796-802.

Zettler, M.L., Proffitt, C.E., Darr, A., Degraer, S., Devriese, L., Greathead, C., Kotta, J., Magni, P., Martin, G., Reiss, H., Speybroeck, J., 2013. On the myths of indicator species: issues and further consideration in the use of static concepts for ecological applications. PloS One 16;8(10):e78219. 
1 Table 1. Description of the experimental sites (nearest town) established in southern Sweden for the comparison of the

2 management methods in semi-natural grassland vegetation. $X$ indicates that the data were used in the present study, while -

3 indicates that existing data were not used (because of the design of data collection).

\begin{tabular}{|c|c|c|c|c|c|c|c|c|c|c|c|c|}
\hline \multirow[t]{2}{*}{ Site } & \multicolumn{5}{|c|}{ Year of inventory } & \multirow[t]{2}{*}{$\begin{array}{c}\text { Vegetation } \\
\text { type }\end{array}$} & \multirow[t]{2}{*}{$\begin{array}{c}\text { Management at start } \\
\text { of trial }\end{array}$} & \multirow[t]{2}{*}{ Soil type } & \multicolumn{4}{|c|}{ Soil characteristics ${ }^{1}$} \\
\hline & 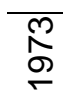 & 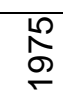 & 商 & 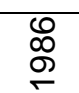 & 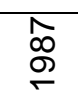 & & & & $\begin{array}{l}N_{\text {Total }} \\
(\%)\end{array}$ & $\mathrm{P}_{\mathrm{Al}}$ & $\mathrm{K}_{\mathrm{Al}}$ & $\begin{array}{c}\text { Organic } \\
\text { content (\%) }\end{array}$ \\
\hline $\begin{array}{l}\text { Österplana } \\
\text { (Götene) }\end{array}$ & - & & $x$ & $x$ & & Dry & Grazing & $\begin{array}{l}\text { Gravelly clay } \\
\text { loam }\end{array}$ & 1.50 & 2.2 & 31.1 & 14.8 \\
\hline $\begin{array}{l}\text { Ekenäs mesic } \\
\text { (Flen) }\end{array}$ & & - & $x$ & $x$ & & Dry-mesic & Grazing & $\begin{array}{l}\text { Humus-rich } \\
\text { loamy }\end{array}$ & 0.33 & 3.4 & 11.7 & 4.6 \\
\hline $\begin{array}{l}\text { Bräcke } \\
\text { (Âmål) }\end{array}$ & $x$ & & $x$ & $x$ & & Mesic & Grazing & Silt & 0.24 & 1.6 & 7.0 & 2.3 \\
\hline $\begin{array}{l}\text { Sättra } \\
\text { (Ödeshög) }\end{array}$ & - & & $x$ & $x$ & & Mesic & Grazing & $\begin{array}{l}\text { Slightly clayey } \\
\text { sand }\end{array}$ & 0.25 & 1.2 & 11.2 & 2.9 \\
\hline $\begin{array}{l}\text { Bråbo } \\
\text { (Oskarshamn) }\end{array}$ & $x$ & & $x$ & $x$ & & Mesic & Grazing & Rocky till & 0.57 & 2.8 & 19.6 & 7.4 \\
\hline $\begin{array}{l}\text { Tagel mesic } \\
\text { (Alvesta) }\end{array}$ & - & & $x$ & $x$ & & Mesic & Grazing & Rocky sand & 0.31 & 1.7 & 10.2 & 4.1 \\
\hline $\begin{array}{l}\text { Tagel former field } \\
\text { (Alvesta) }\end{array}$ & - & & & & $x$ & Mesic & Grazing, fertilized & Rocky till & 0.26 & 6.6 & 15.4 & 3.0 \\
\hline $\begin{array}{l}\text { Dämkärr } \\
\text { (Gamleby) }\end{array}$ & - & & & $x$ & & Mesic & $\begin{array}{l}\text { No management for } 3 \\
\text { years }\end{array}$ & Humus-rich silt & 0.31 & 1.3 & 12.5 & 4.2 \\
\hline $\begin{array}{l}\text { Gränö } \\
\text { (Värmdö) }\end{array}$ & - & & & $x$ & & Moist & Mowing, fertilized & $\begin{array}{l}\text { Slightly humus- } \\
\text { rich silt }\end{array}$ & 0.20 & 1.7 & 13.9 & 2.6 \\
\hline $\begin{array}{l}\text { Ekenäs moist } \\
\text { (Flen) }\end{array}$ & & $x$ & & $x$ & & Moist & Grazing & $\begin{array}{l}\text { Highly humus- } \\
\text { rich light clay }\end{array}$ & 0.92 & 3.2 & 22.9 & 13.3 \\
\hline
\end{tabular}


Andersby

$X \quad X \quad X \quad$ Moist

Grazing

Humus-rich

light clay

1.30

4.0

24.2

15.5

${ }^{1}$ Steen 1976 
5 Fig. 1. Study locations in southern Sweden. Ekenäs and Tagel had two

6 experimental sites each.

7 Fig. 2. $\ln ($ RR-values) for the (A) number of species, (B) Shannon

8 diversity, (C) Shannon evenness, and (D) Gini-Simpson diversity. Trials

9 were run for 11 to 14 years (see text). A negative value means lower

10 diversity or evenness in mowing every third year (solid symbols, solid

11 bars) or in the untreated control (open symbols, hatched bars), compared

12 with annual mowing. Bars represent 95\% confidence intervals. Note the

13 differences in scale on the $x$-axes. Trials are ordered from dry/species-

14 rich to moist/species-poor. Asterisks indicate trials that had been

15 fertilized or abandoned for a few years before the start of the treatment.

16 Fig. 3. Development of $\ln (R R)$-values over time for the eight trials with

17 comparable data. M0 represents untreated control, M1 mowing annually

18 and M3 mowing every third year. In the pairs, the lower value is an

19 average and the upper value is a weighted average, where trials with

20 three surveys are given a larger weight in calculations compared with

21 those surveyed only twice.). Bars are 95\% confidence interval. A negative

22 value means that the number of species, biodiversity or evenness is

23 higher in annual mowing than in the alternative treatment. 
24 Fig. 4. Development of $\ln (R R)$ of species number over time in individual

25 trials. M0 represents untreated control, M1 mowing annually and M3

26 mowing every third year. (A) mowing every third year compared with

27 annual mowing (B) untreated control compared with annual mowing. A

28 negative value means that the number of species is higher in annual

29 mowing than in the alternative treatment. Small circles indicate trials

30 that had been fertilized or abandoned for a few years before the start of

31 the treatment and that had only been surveyed once using the

32 standardized protocol for vegetation sampling.

33 Fig. 5. The development of the species number recorded in the long-term

34 trial at Sättra and expressed as the difference between M1 (annual

35 mowing) and M3 (mowing every third year) or MO (untreated control).

36 The untreated control (M0) was not inventoried after 38 years because it

37 by then had developed into a very dense forest.

38 Fig. 6. Ln(OR) contrasting mowing annually with mowing every third

39 year for indicators of good management and/or poor management. Bars

40 are 95\% confidence interval. Positive values indicate most in plots

41 mowed annually while negative most in those mowed every 3rd year.

42 Fig. 7. Species-wise responses after 11, 13 or 14 years of differing

43 treatments. A negative value means that a species is decreasing when the

44 mowing frequency decreases compared with annual mowing. The 
45 indicator status of species is shown with $a+$ or -, for good and poor

46 management indicators, respectively (based on Ekstam \& Forshed 1992).

47 Numbers to the right are the number of blocks that had an occurrence

48 (max. $=22)$; species with $<7$ are not shown. Bars are 95\% confidence

49 interval

50 Fig. 8. Differences between the two mowing treatments (annual and every

51 third year) per species ( $N=57)$ as a function of the species' log plant

52 height. The latter was according to the LEDA traitbase, while differences

53 were according to eleven field trials after 11-14 years (see Fig. 7). 


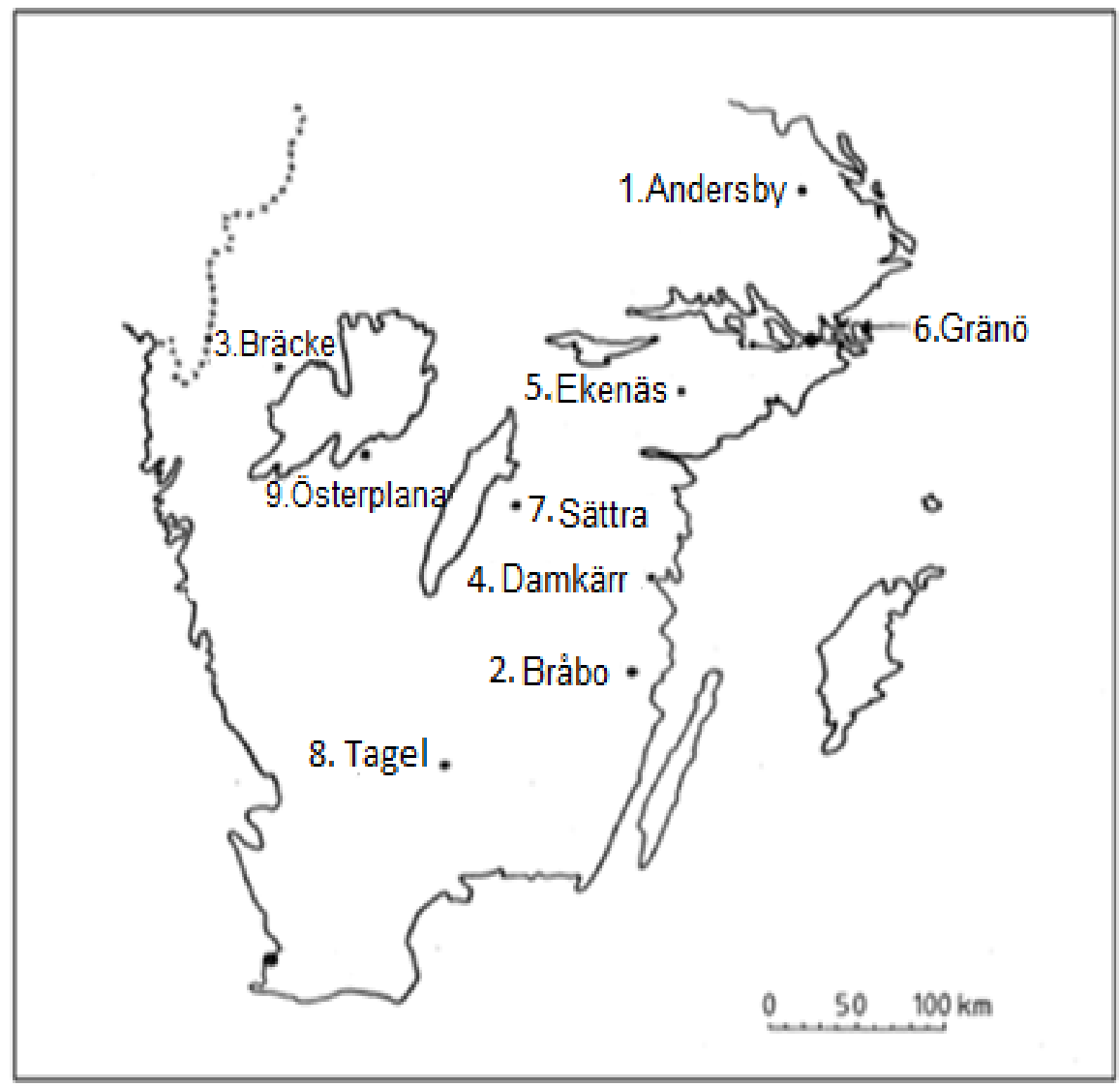

Fig. 1. Study locations in southern Sweden. Ekenäs and Tagel had two experimental sites each. 

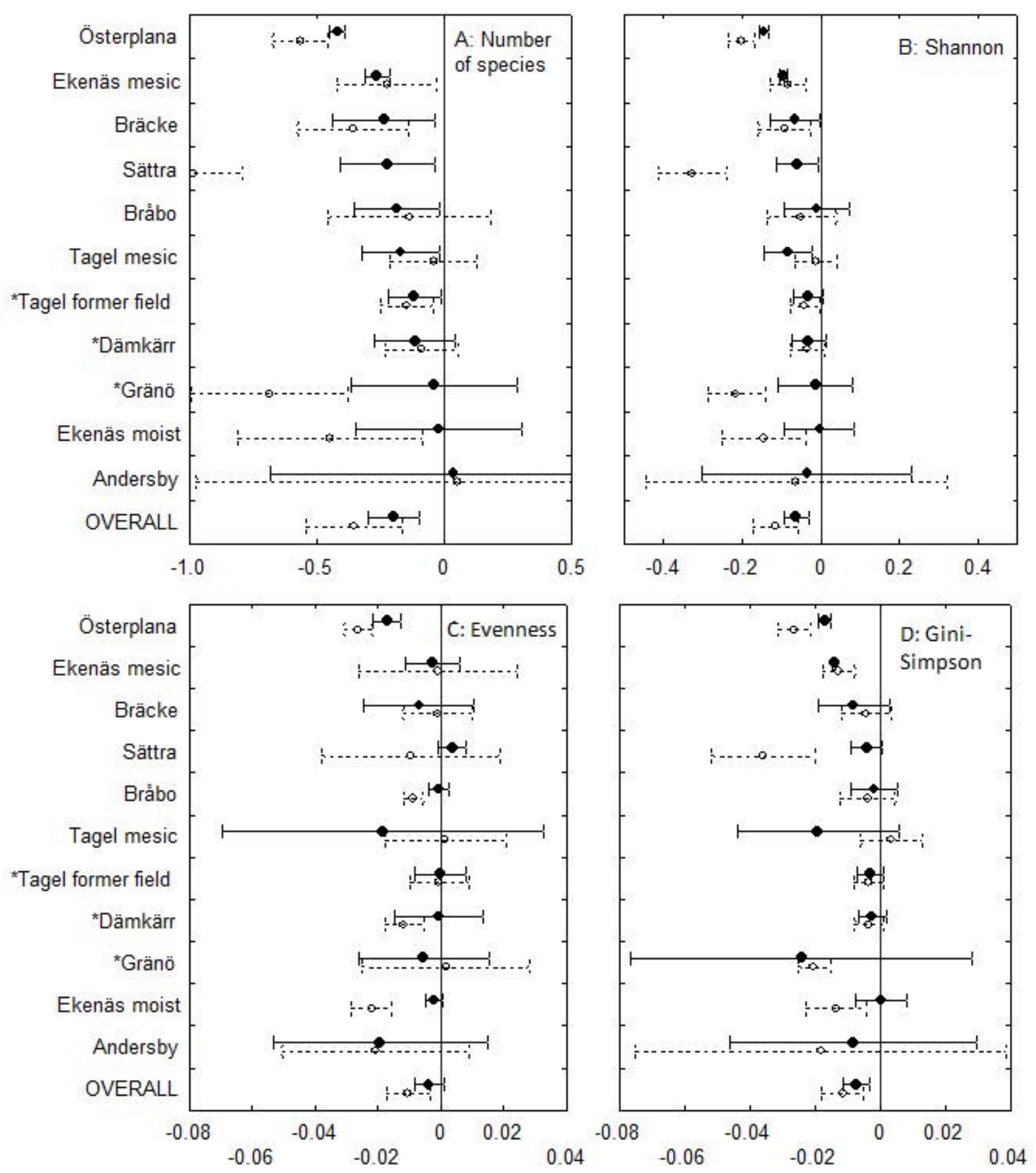

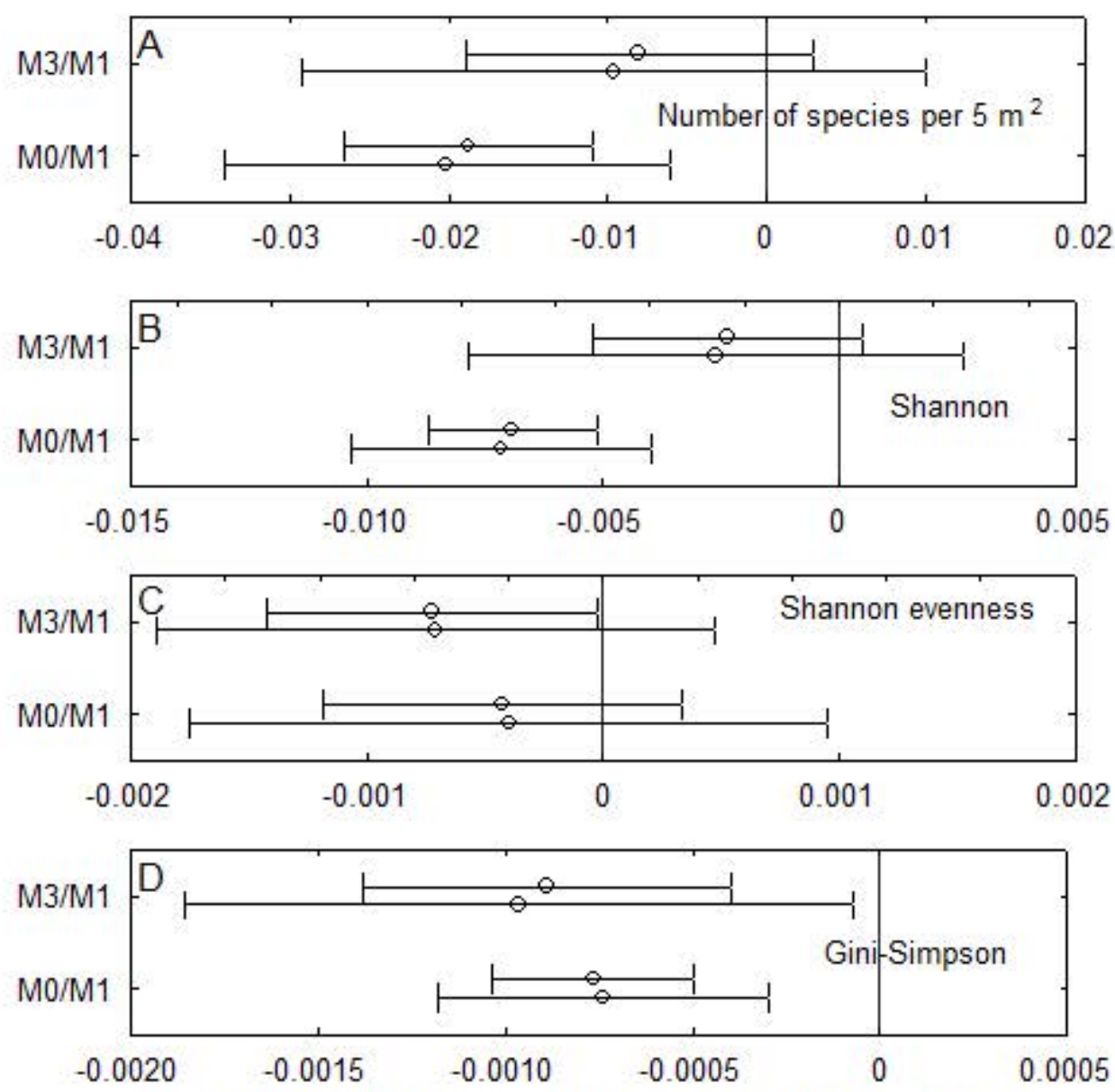

Slope in In(RR) (i.e.change per year comparing M0/M1 or M3/M1) 

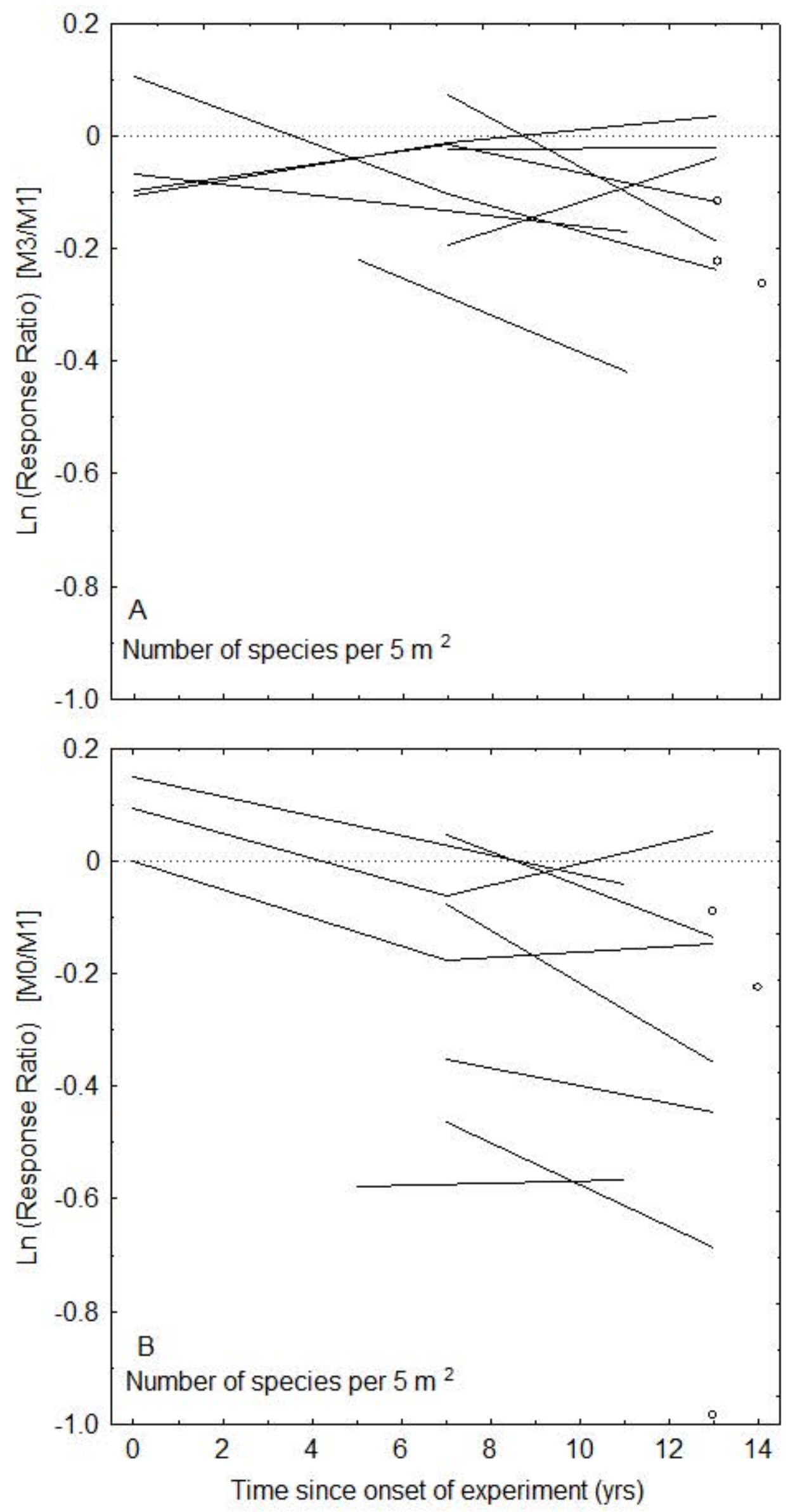


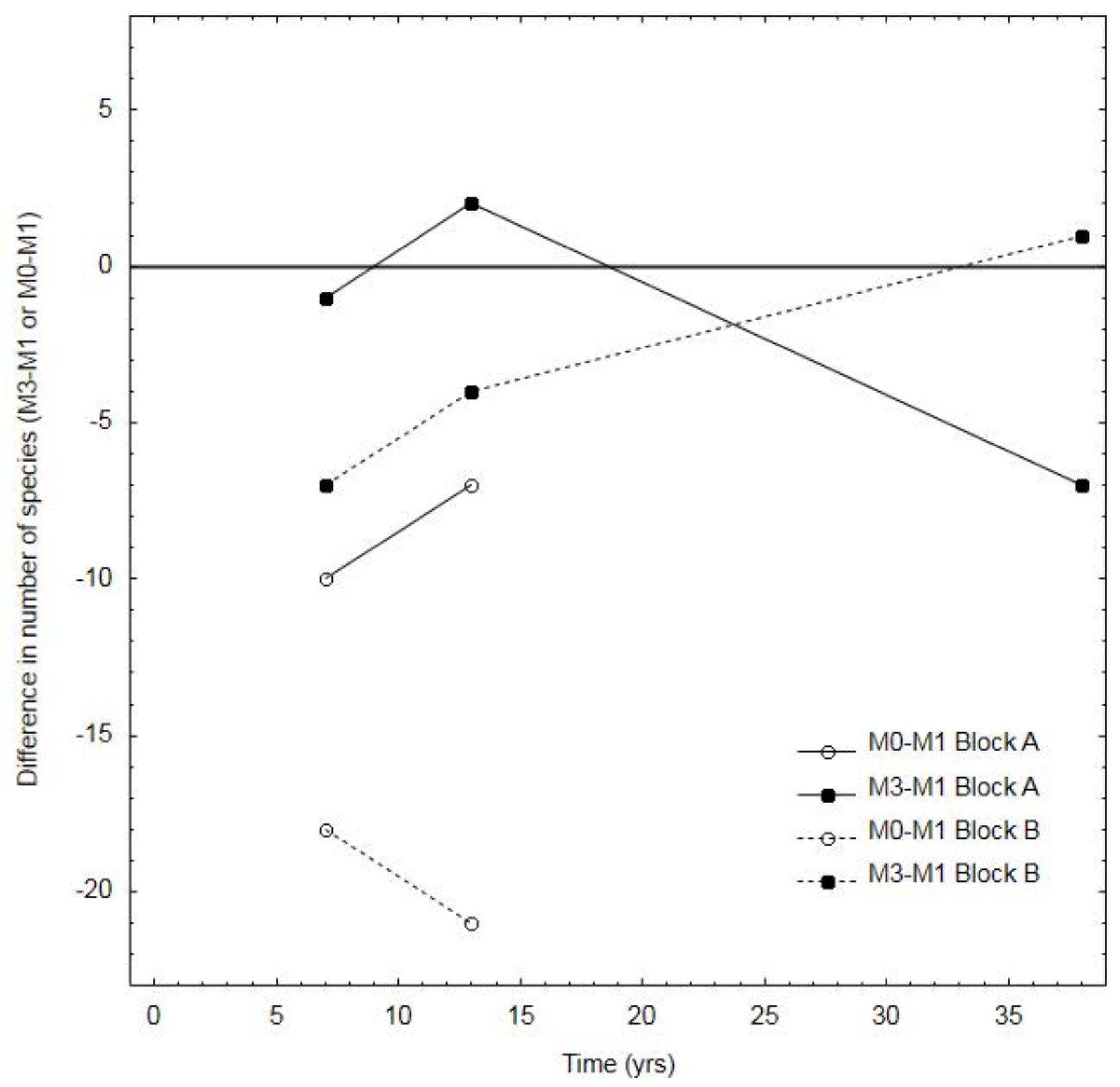


Anthoxanthum odoratum Cerastium fontanum

- Luzula multiflora

+ Festuca ovina

Leucanthemum vulgare

+ Campanula rotundifolia

Phleum pratense

+ Lathyrus linifolius

Alchemilla spp

Ranunculus acris

- Potentilla erecta

Rumex acetosa

Ranunculus auricomus

- Fragaria vesca

Plantago lanceolata

+ Briza media

Taraxacum sect. Ruderalia

Centaurea jacea

+ Trifolium pratense

Festuca pratensis

- Lathyrus pratensis

Primula veris

- Stellaria graminea

Galium album

+ Galium uliginosum

Veronica chamaedrys

+ Pimpinella saxifraga

- Deschampsia cespitosa

other Agrostis spp.

- Geum rivale

- Anemone nemorosa

- Galium verum

Poa pratensis

Festuca rubra

Achillea millefolium

- Galium boreale

- Trifolium medium

- Hypericum maculatum

- Helictotrichon pratense

Filipendula ulmaria

Elytrigia repens

- Vicia cracca

+ Anthriscus sylvestris

Carex pallescens

Dactylis glomerata

Woody spp.

+ (3rd yr mowing)-(annual mowinḡg)

(Control)-(annual mowing) 


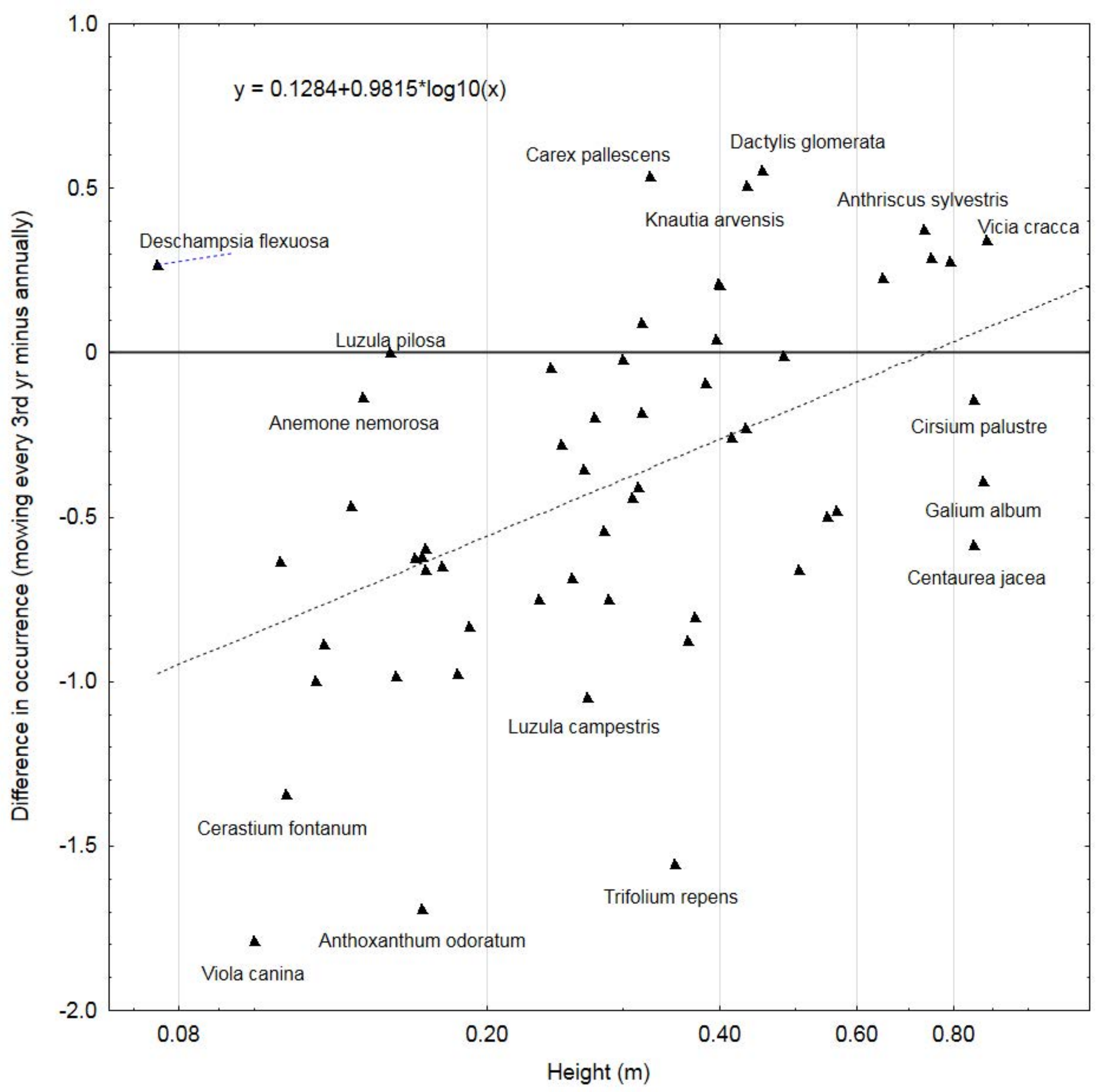

